\title{
SUPPORTING GENERATION AND DISTRIBUTION OF ENERGY ORIGINATING FROM RENEWABLE SOURCES IN KUJAWSKO-POMORSKIE PROVINCE
}

Izabela Wielewska ${ }^{1}, \mathrm{PhD}$; Monika Zajakala ${ }^{2}, \mathrm{PhD}$ Student

1,2UTP University of Science and Technology in Bydgoszcz, Poland

\begin{abstract}
Supporting generation and distribution of energy from renewable sources enables energy efficiency and security to increase. Kujawsko-pomorskie Province is at the forefront amongst other provinces in Poland and readily implements the assumptions of the energy policy based on renewable energy sources. As part of the Regional Operational Program of Kujawsko-pomorskie Province, the Marshal's Office in Torun conducted activities supporting the production and distribution of energy coming from renewable sources in 2018, addressed at the inhabitants of the province. Boroughs were the applicants obliged to obtain information from residents about the demand for renewable energy. One of the beneficiaries was an urban-rural borough, located in the county of Bydgoszcz. Therefore, research was carried out whose aim was to analyse the applications submitted, taking into account the type of installation, its capacity and the place of residence of the beneficiaries of Action 3.1 "Supporting generation and distribution of energy from renewable sources" in the borough of Koronowo.

The research showed that the borough did not use the available pool of funds for the action. 51 applications were submitted, in which requests for photovoltaic, solar and air heat pumps were formulated. Investment opportunities for the generation and distribution of energy from renewable sources were more eagerly used by rural residents than those of the cities. The largest interest was shown for photovoltaic installations, whose average requested power was $1 \mathrm{~kW}$ higher than for the installations declared in the city and amounted to $7.41 \mathrm{~kW}$.
\end{abstract}

Key words: renewable energy sources, Kujawsko-pomorskie province, Koronowo borough, support for renewable energy installations.

JEL code: D25, 013, Q42.

\section{Introduction}

According to European regulations, the share of energy from renewable sources in Poland's energy balance by 2020 is expected to be at least $15 \%$. It is therefore justified to support measures for the generation and distribution of energy from renewable sources (Szczerbowski R., Ceran B., 2013; Wielewska I., Plonka A., Kupczyk A., 2018; Mickiewicz B., Zuzek D., 2012). This idea fully implements the assumptions of sustainable development of urban and rural areas, which requires support from the country's policy. In terms of geographical and environmental conditions, Poland is a good place for the production of renewable energy. Modern technologies lead to the obtainment of better and better results of energy production, without disturbing the ecosystem (Snarski S.J., 2015). The current way of using energy does not correspond to the rules of managing sustainable development. In a balanced transformation of the energy sector, a priority role should be played by of the environmental burden due to generation and supply of various forms of energy to the recipients as well as the reduction of primal fossil energy media, the reduction of the extent of dependence of producing various forms of energy on these resources while maintaining the current level of energy services (Wielewska I., 2016).

It should be noted that ecological investments contribute to restraining the progressing degradation of the environment and activities recognized as ecologically harmful (Wielewska I., 2015), therefore it is not possible to talk about sustainable development in the field of energy without taking into account renewable energy sources (RES).

Local government units of all levels are increasingly willing to take action to create renewable energy sources (RES). They may be investors in such tasks or beneficiaries thereof. Measurable benefits from the introduction of energy from RES are particularly important in terms of

\footnotetext{
${ }^{1}$ E-mail: izabel2000@wp.pl, tel. +48 523408047

2 E-mail: monika_zaręba@interia.pl
} 
environmental protection and ensuring energy security. Boroughs are perfect places for the development of this type of investment, which is why aid programs are increasingly often dedicated to these entities. The allocation of public aid funds appropriated for renewable energy for boroughs becomes an opportunity for them to attract investors' interest, and - in effect - for economic development, greater competitiveness and promotion of the borough in Poland and in the world (Sasinowski M., 2017).

In recent years, there has been an increase in the interest in alternative energy sources. This is directly related to the growing problem of smog in the country, the possibility of depletion of lignite and hard coal deposits and ever higher prices of electricity. However, the RES potential in Poland is still poorly used, which is closely related to the economic calculation. Therefore, it is crucial to support renewable energy, which is a priority for energy policy for the coming decades. Co-financing of investments related to the production of renewable energy is the basic driver of development and willingness to make changes. It results primarily from the level of own contribution in the investment acceptable by natural persons, with partial coverage of the total costs from the state budget and the European Union (Sobczyk W., Baran T., 2016).

The primary renewable energy source is solar energy, whose annual energy potential is 15 thousand times larger than the energy resources coming from fossil fuels and nuclear energy combined. Wind energy, water, geothermal energy as well as energy from biogas and biomass should also be included in renewable sources. Kujawsko-pomorskie Province, alongside Pomeranian and Silesian Provinces, is the leader of the country in terms of the use of renewable energy sources (Krupnik K., Brozek M., 2008).

The recruitment bodies for activities supporting the development of renewable energy are the Marshals' Offices. Boroughs, as the basic units of the local government which have an influence on the energy policy, may apply for co-financing for this purpose. One of the boroughs which collected data from the interested property owners about the demand for renewable energy sources and applied for co-financing for this purpose, as part of the recruitment for Action 3.1 "Supporting generation and distribution of energy from renewable sources", was the borough of Koronowo.

In connection with the above, a review was carried out of activities in the area of raising funds for the generation and distribution of energy from renewable sources of the borough of Koronowo, an urban-rural commune located in Kujawsko-pomorskie Province.

The aim of the study was to analyse the submitted applications, taking into account the type of installation, its power, costs and place of residence of the beneficiaries of Action 3.1 "Supporting generation and distribution of energy from renewable sources" that are owners of residential buildings in the Koronowo commune. The study also presents the estimated costs of assembling the solar installation most frequently chosen in the photovoltaic installation program, as well as the calculation based on the average energy consumption before the project implementation, regarding the length of use, followed by the return of costs incurred for the investment.

\section{Material and methods}

The intake of applications under Action 3.1 "Supporting generation and distribution of energy from renewable sources, scheme: microinstallations, scheme 1: residential and public buildings (excluding healthcare infrastructure)" was run from 20 August to 14 December 2018 by the Marshal's Office in Torun (competition no. RPKP.03.01.00- IZ.00-04-212/18). Funds for the implementation of the program came from the Regional Operational Program of Kujawsko-pomorskie Province. Eligible 
applicants were local government units, cooperatives and housing communities, social housing associations and non-governmental organizations. The maximum co-financing per unit was PLN 1 million (www.mojregion.eu).

The research was conducted on the basis of data from the application submitted by the borough of Koronowo, located in the county of Bydgoszcz, in Kujawsko-pomorskie Province. It is an urbanrural commune occupying an area of $412 \mathrm{~km}^{2}$, in which there are 23655 residents, of whom 10740 reside within the city limits. In the borough, the majority of residents are registered in rural areas (54.6\%), inhabiting 33 villages. According to the data of the Koronowo Town and Borough Office, as of 31 December 2018, the most people in rural areas lived in Makowarsko (1326 inhabitants), Tryszczyn (1069 people) and WtelNo (1020 registered). The smallest communities in terms of population are Skarbiewo, Osiek and Popielewo, in which there are fewer than 100 residents (www.bip.koronowo.pl, www.bydgoszcz.stat.gov.pl). The population in Koronowo and the villages is presented in Table 2.

The information on the application submitted by the borough for co-financing activities supporting generation and distribution of renewable energy was obtained from the Koronowo Town and Borough Office, which prepared the competition documentation based on data collected from the interested property owners, including the technical design of the proposed installations. The subsidy was intended for natural persons living in the borough and did not include business or agricultural activities. Any equipment for generating energy from renewable sources can only be used for household purposes. The installations can be mounted on existing or constructed buildings, subject to technical acceptance by the end of April 2019. Promotional activities aimed at dissemination of Action 3.1. were conducted through the organization of regular meetings with the residents of Koronowo and the surrounding area. In total, 4 meetings were organized, with the participation of communal officials and technical specialists in the field of assembling installations for the production of energy from renewable sources. The meetings took place in Koronowo, Tryszczyn, Makowarsko and Wierzchucin Krolewski.

As part of the activities supporting the generation and distribution of energy from renewable sources, property owners were able to apply for partial co-financing of the incurred net eligible costs at the level of up to $50 \%$. The calculation of the co-financing level was made on the basis of the mathematical product of the net costs incurred and the maximum level of return. Despite the intended use of energy for the sole needs of households, the installations could be designed on other buildings owned by the applicant. When choosing a mounting location, especially for photovoltaic and solar installations, the key was the selection of a place with the best possible insolation. The choice of the place was related to the VAT tax difference, which amounted to $8 \%$ for the installations on or in a residential building, while it was $23 \%$ for the assembly on or in an outbuilding or on the surface of the land. Having taken into account the VAT rates, the total co-financing amount was about $46 \%$ when assembled within a residential building and about $42 \%$ for installations on the ground or an outbuilding. The rated capacity of the installation was determined on the basis of average values of electricity bills, and the maximum investment cost for a natural person could not exceed 100,000. zt. The beneficiaries could apply for the installation of solar installations, air pumps for the purposes of heating utility water, photovoltaic installations and pellet boilers.

In order to analyse the length of the investment return period related to the mounting of photovoltaic installations, the data regarding net costs of installations indicated by the Koronowo Town and Borough Office were used. The owners of residential buildings, who were reporting the 
need for a solar installation, were obliged to submit a technical design in which the planned installation capacity was taken into account, through an enterprise involved in the assembly of such devices. Its size was determined based on the average annual energy consumption. The beneficiaries of the program were able to submit projects with power levels in the 1.74-9.86 kW range. The installations with the smallest power $(1.74 \mathrm{~kW})$ were selected by those households whose annual sum of costs related to paying electric bills amounts to about PLN 900. The installation with the largest capacity available in the program $(9.86 \mathrm{~kW})$ was addressed at residents who spend about PLN 5,400 per year for this purpose. An example of a list including the costs incurred for electricity before the RES investments were made and the related demand for installation capacity and costs are presented in Table 1.

Table 1

Costs of the making of photovoltaic installations depending on their power

\begin{tabular}{|c|c|c|c|c|c|}
\hline No & $\begin{array}{l}\text { Cost of electricity } \\
\text { (PLN/month) }\end{array}$ & $\begin{array}{l}\text { Power of photovoltaic } \\
\text { installation (kW) }\end{array}$ & $\begin{array}{c}\text { Net cost of } \\
\text { installation net } \\
(\text { PLN })\end{array}$ & $\begin{array}{l}\text { Gross cost } \\
\text { (VAT } 8 \% \text { ) }\end{array}$ & $\begin{array}{l}\text { Gross cost } \\
\text { (VAT } 23 \% \text { ) }\end{array}$ \\
\hline 1. & 75 & 1.74 & 6202.78 & 6699.00 & 7629.42 \\
\hline 2. & 100 & 2.32 & 8270.37 & 8932.00 & 10172.56 \\
\hline 3. & 125 & 2.61 & 9304.17 & 10048.50 & 11444.13 \\
\hline 4. & 150 & 3.19 & 11371.76 & 12281.50 & 13987.26 \\
\hline 5. & 175 & 3.77 & 13439.35 & 14514.50 & 16530.40 \\
\hline 6. & 200 & 4.35 & 15506.94 & 16747.50 & 19073.54 \\
\hline 7. & 225 & 4.93 & 17574.54 & 18980.50 & 21616.68 \\
\hline 8. & 250 & 5.51 & 19642.13 & 21213.50 & 24159.82 \\
\hline 9. & 275 & 6.09 & 21709.72 & 23446.50 & 26702.96 \\
\hline 10. & 300 & 6.67 & 23777.31 & 25679.49 & 29246.09 \\
\hline 11. & 325 & 6.96 & 24811.11 & 26796.00 & 30517.67 \\
\hline 12. & 350 & 7.54 & 26878.7 & 29029.00 & 33060.80 \\
\hline 13. & 375 & 8.12 & 28946.3 & 31262.00 & 35603.95 \\
\hline 14. & 400 & 8.7 & 31013.89 & 33495.00 & 38147.08 \\
\hline 15. & 425 & 9.28 & 33081.48 & 35728.00 & 40690.22 \\
\hline 16. & 450 & 9.86 & 35149.07 & 37961.00 & 43233.36 \\
\hline
\end{tabular}

Source: author's own study based on the data from The Koronowo Town and Borough Office

In the research, a comparative analysis was made of the time needed to repay the investment carried out in-house, without the use of financial assistance and after receiving co-financing with two possibilities of the assembly location and the associated VAT rate: within a residential building ( $8 \%)$ as well as within an outbuilding or on the ground ( $23 \%)$. In order to calculate the length of the investment repayment period, which could be made without public funding, the calculated gross costs were divided by the amount of monthly electricity bills. The investment return time, which was carried out under Action 3.1, was calculated on the basis of the quotient of own contribution and the sum of electricity bills for one month. For this purpose, the co-financing amount was calculated first (net cost $\times 50 \%$ ), and then it was subtracted from gross amounts accounting for $8 \%$ and $23 \%$ VAT. Analogically to the previous analysis, the obtained costs are divided by the value of monthly bills for electricity. 


\section{Research results and discussion}

The total eligible cost of the project in the commune amounted to PLN 1,033,940.00 net, using the available pool of funds in approximately $50 \%$. The residents of the borough of Koronowo submitted 51 applications for installations with a total capacity of $315.44 \mathrm{~kW}$. A demand was submitted for 1 solar installation with a capacity of $11.6 \mathrm{~kW}$ and 7 air heat pumps with a total capacity of $17.5 \mathrm{~kW}$. There was No interest in assembling pellet boilers. The detailed data on the number and scope of applications, taking into account the place of residence of the beneficiaries, are presented in Table 2.

Table 2

The number of applications for Action 3.1 submitted in the borough of Koronowo by the place of residence of the beneficiaries

\begin{tabular}{|c|c|c|c|c|c|c|c|}
\hline \multirow[b]{2}{*}{ No } & \multirow{2}{*}{$\begin{array}{c}\text { Place of } \\
\text { residence of } \\
\text { beneficiaries }\end{array}$} & \multicolumn{2}{|c|}{ Number of } & \multirow{2}{*}{$\begin{array}{c}\text { Total } \\
\text { power of } \\
\text { installation } \\
{[\mathbf{k W}]}\end{array}$} & \multicolumn{3}{|c|}{ Requested number of } \\
\hline & & residents & applications & & $\begin{array}{c}\text { heat } \\
\text { pumps }\end{array}$ & $\begin{array}{l}\text { photovoltaic } \\
\text { installations }\end{array}$ & $\begin{array}{c}\text { solar } \\
\text { installations }\end{array}$ \\
\hline 1. & Buszkowo & 401 & 3 & 13.92 & 0 & 3 & 0 \\
\hline 2. & Gogolin & 236 & 2 & 16.82 & 0 & 2 & 0 \\
\hline 3. & Gogolinek & 164 & 1 & 11.6 & 0 & 0 & 1 \\
\hline 4. & Goscieradz & 441 & 2 & 18.56 & 0 & 2 & 0 \\
\hline 5. & Koronowo & 10740 & 11 & 66.59 & 1 & 10 & 0 \\
\hline 6. & Lucim & 543 & 3 & 21.06 & 1 & 2 & 0 \\
\hline 7. & Lasko Male & 199 & 1 & 6.38 & 0 & 1 & 0 \\
\hline 8. & Makowarsko & 1326 & 3 & 13.34 & 0 & 3 & 0 \\
\hline 9. & Morzewiec & 192 & 3 & 18.74 & 1 & 2 & 0 \\
\hline 10. & Okole & 684 & 2 & 8.3 & 1 & 1 & 0 \\
\hline 11. & Samociazek & 539 & 1 & 1.74 & 0 & 1 & 0 \\
\hline 12. & Sitowiec & 199 & 1 & 9.86 & 0 & 1 & 0 \\
\hline 13. & Tryszczyn & 1069 & 14 & 82.14 & 3 & 11 & 0 \\
\hline 14. & Wiezowno & 410 & 1 & 9.86 & 0 & 1 & 0 \\
\hline 15. & Witoldowo & 360 & 2 & 11.02 & 0 & 2 & 0 \\
\hline 16. & Wtelno & 1020 & 1 & 5.51 & 0 & 1 & 0 \\
\hline & Total & & 51 & 315.44 & 7 & 43 & 1 \\
\hline
\end{tabular}

Source: author's own study based on the data from The Koronowo Town and Borough Office

The rural inhabitants more frequently applied for financial aid under RES as they submitted 40 applications for granting financial aid. Among the beneficiaries from these areas were people living in 15 villages of the Koronowo borough. The percentage of applications submitted by these residents per one rural inhabitant amounted to 0.003 , and for city residents only 0.001 . In Makowarsko - the largest village commune of the Koronowo borough, with 1326 inhabitants, only three installations for the production and distribution of energy from renewable sources were reported. The same number of applications was recorded in Morzewiec (192 inhabitants), Buszkowo (402 inhabitants) and Lucim (543 inhabitants). The inhabitants who showed the greatest interest were those of Tryszczyn the population of which is 257 people smaller than that of Makowarsko and nearly ten times smaller than that of Koronowo. The owners of real estate located in this town have planned the installation of 11 photovoltaic installations and 3 heat pumps. In nearby Wtelno, where more than one thousand people are registered inhabitants, a grant for one installation with a capacity of $5.51 \mathrm{~kW}$ has been applied for. In other villages, one or two odd applications were submitted. Among the renewable energy sources that could be selected as part of the program, the most popular were photovoltaic installations, which constituted $82.98 \%$ of the total submitted applications, with a total 
capacity of $286.34 \mathrm{~kW}$. The smallest requested installation with a power of $1.74 \mathrm{~kW}$ was declared on a residential home in Samociazek. Among 43 applications related to energy obtained from photovoltaics, 9 technical projects assumed the use of the maximum power for this type of installation under the co-financing, that is $9.86 \mathrm{~kW}$. The applicants were the residents of Tryszczyn (2 installations), Koronowo, Lucim, Goscieradz, Sitowiec, Morzewiec, Gogolin and WiezowNo (1 installation each).

The residents of Koronowo submitted 10 applications in which photovoltaic installations with a total power of $64.09 \mathrm{~kW}$ were requested (Table 3).

Table 3

\section{Data on photovoltaic installations requested by the city residents}

\begin{tabular}{|l|c|c|}
\hline No & $\begin{array}{c}\text { Rated power } \\
{[\mathbf{k W}]}\end{array}$ & $\begin{array}{c}\text { Number of panels } \\
\text { [pcs] }\end{array}$ \\
\hline $\mathbf{1 .}$ & 3.48 & 12 \\
\hline $\mathbf{2 .}$ & 4.35 & 15 \\
\hline $\mathbf{3 .}$ & 4.93 & 17 \\
\hline $\mathbf{4 .}$ & 5.51 & 19 \\
\hline $\mathbf{5 .}$ & 6.67 & 23 \\
\hline $\mathbf{6 .}$ & 6.96 & 24 \\
\hline $\mathbf{7 .}$ & 6.96 & 24 \\
\hline $\mathbf{8 .}$ & 7.25 & 25 \\
\hline $\mathbf{9 .}$ & 8.12 & 28 \\
\hline $\mathbf{1 0 .}$ & 9.86 & 34 \\
\hline Total & 64.09 & 221 \\
\hline
\end{tabular}

Source: author's own study based on the data from The Koronowo Town and Borough Office

The household demand from the city of Koronowo for energy coming from photovoltaic systems amounted to an average of $6.41 \mathrm{~kW}$. In rural areas, installations with a total capacity of $248.85 \mathrm{~kW}$ were reported, of which $222.25 \mathrm{~kW}$ for photovoltaic panels. The average power of the proposed installation using the photovoltaic effect in the villages was $7.41 \mathrm{~kW}$.

The calculations clearly proved that the return period of investments in the installation of photovoltaic panels implemented with the use of public funds was on average 39 months shorter for assembly in both residential and outbuildings or on the ground than private installation of renewable energy installations (Table 4). The longest return period was for photovoltaic installations with 1.74 $\mathrm{kW}$ and $2.32 \mathrm{~kW}$. In the case of private investments, covering the assembly costs is estimated at nearly 90 and 102 months, depending on its location. The full reimbursement therefore occurs after 7.5-8.5 years of use. With the use of the co-financing, this time is shortened to 4-5 years of owning a renewable energy source. According to the calculations, the return period of the remaining sizes of installations is shorter. The most economical was the installation with a capacity of $2.61 \mathrm{~kW}$, which covers monthly electricity bills amounting to PLN 125 . The return period of own contribution under Action 3.1 on a residential building was only 3.5 years and a year longer if the investment was made on another building or the ground. Failure to receive public funds extends the return period of the same installation by more than 3 or 4 years.

The installation with the maximum power $(9.86 \mathrm{~kW})$ available as part of the action that enjoyed the greatest interest when assembling within a residential home returns after 3 years and 9 months, and for installations in other permitted places - in less than five years. 
Time of return of investments carried out on residential buildings (VAT $8 \%$ ), on an outbuilding or the ground (VAT $23 \%$ ), in RES investments carried out without subsidies and with co-financing

\begin{tabular}{|c|c|c|c|c|c|}
\hline \multirow[b]{2}{*}{ No } & \multirow[b]{2}{*}{$\begin{array}{c}\text { Power of } \\
\text { installation } \\
{[\mathbf{k W}]}\end{array}$} & \multicolumn{4}{|c|}{ Average return on investment in months } \\
\hline & & $\begin{array}{l}\text { Investment } \\
\text { carried out } \\
\text { privately, } \\
\text { VAT } 8 \%\end{array}$ & $\begin{array}{c}\text { Investment } \\
\text { carried out } \\
\text { privately, VAT } \\
23 \%\end{array}$ & $\begin{array}{c}\text { Investment } \\
\text { carried out with } \\
\text { co-financing, VAT } \\
8 \%\end{array}$ & $\begin{array}{c}\text { Investment } \\
\text { carried out with } \\
\text { co-financing, VAT } \\
23 \%\end{array}$ \\
\hline 1. & 1.74 & 89.32 & 101.73 & 47.97 & 60.37 \\
\hline 2. & 2.32 & 89.32 & 101.73 & 47.97 & 60.37 \\
\hline 3. & 2.61 & 80.39 & 91.55 & 43.17 & 54.34 \\
\hline 4. & 3.19 & 81.88 & 93.25 & 43.97 & 55.34 \\
\hline 5. & 3.77 & 82.94 & 94.46 & 44.54 & 56.06 \\
\hline 6. & 4.35 & 83.74 & 95.37 & 44.97 & 56.60 \\
\hline 7. & 4.93 & 84.36 & 96.07 & 45.30 & 57.02 \\
\hline 8. & 5.51 & 84.85 & 96.64 & 45.57 & 57.36 \\
\hline 9. & 6.09 & 85.26 & 97.10 & 45.79 & 57.63 \\
\hline 10. & 6.67 & 85.60 & 97.49 & 45.97 & 57.86 \\
\hline 11. & 6.96 & 82.45 & 93.90 & 44.28 & 55.73 \\
\hline 12. & 7.54 & 82.94 & 94.46 & 44.54 & 56.06 \\
\hline 13. & 8.12 & 83.37 & 94.94 & 44.77 & 56.35 \\
\hline 14. & 8.70 & 83.74 & 95.37 & 44.97 & 56.60 \\
\hline 15. & 9.28 & 84.07 & 95.74 & 45.15 & 56.82 \\
\hline 16. & 9.86 & 84.36 & 96.07 & 45.30 & 57.02 \\
\hline & Average & 84.29 & 95.99 & 45.26 & 56.97 \\
\hline
\end{tabular}

Source: author's own study based on the data from The Koronowo Town and Borough Office

The interest in air heat pumps for hot utility water was over six times smaller than that in photovoltaics. There were 7 applications registered in the borough, of which 6 came from rural areas. All pumps in technical designs had a capacity of $2.5 \mathrm{~kW}$, which covers the daily demand for hot water for 3-5 people permanently living in the household, which amounts to an average of 300 litres.

One application, the beneficiary of which was a resident of Gogolinek, concerned the demand for a solar installation with a surface of $5.7 \mathrm{~m} 2$ and a capacity of $11.6 \mathrm{~kW}$.

\section{Conclusions}

1) The borough of Koronowo (an urban-rural commune), as one of the largest regions in Kujawskopomorskie Province, only used half of the possibilities of supporting activities for renewable energy sources.

2) Rural residents, rather than those of cities, were more eager to use investment support to generate and distribute energy from renewable sources.

3) Most applications were received from the village of Tryszczyn, which may be related its close vicinity of the city of Bydgoszcz and numerous housing investments in this town undertaken recently. 
4) The greatest interest of the inhabitants of the Koronowo borough was demonstrated for activities involving the installation of photovoltaics. Other micro-installations were chosen to a rather small extent (heat pumps, solar panels). No demand for pellet boilers was reported.

5) Photovoltaic installations with an average power of $1 \mathrm{~kW}$ higher than the same installations in the city were selected for installation in rural areas.

6) The return period of investments made with the share of public funds was on average 39 months shorter than in the case of private installation of RES installations and amounted to 3 years and 9 months for assembly in a residential house and 4 years and 8 months for assembly in/on other buildings or on the ground.

7) The installations with the smallest power: $1.74 \mathrm{~kW}$ and $2.32 \mathrm{~kW}$ were characterized by the longest period needed to return the investment. Persons reporting the demand for such power spend 900-1200 PLN annually on electricity bills.

\section{Bibliography}

1. Gmina miejsko-wiejska Koronowo, powiat bydgoski (The urban-rural borough of Koronowo, the county of Bydgoszcz), www.bydgoszcz.stat.gov.pl/vademecum/ vademecum_kujawsko-

pomorskie/portrety_gmin/powiat_bydgoski/gmina_koronowo.pdf. Access: 21.01.2019.

2. Krupnik, K., Brozek, M. (2008). Eko-rozwoj terenow wiejskich a odnawialne zrodla energii (Ecodevelopment of countryside with renewable energy sources aspect), Infrastruktura i ekologia terenow wiejskich. No 3, pp. 93-101.

3. Lorenc, J., Dzialanie 3.1. Wspieranie wytwarzania i dystrybucji energii pochodzacej ze zrodel odnawialnych, konkurs nr RPKP.03.01.00-IZ.00-04-212/18 (Action 3.1. Supporting generation and distribution of energy from renewable sources, competition no. RPKP.03.01.00-IZ.00-04-212/18), www.mojregion.eu/index.php/rpo/zobacz-ogloszenia?mmid=258. Access: 18.01.2019.

4. Materialy Urzedu Miasta i Gminy Koronowo na temat instalacji OZE (Materials from the Koronowo Town and Borough Office on RES installations).

5. Mickiewicz B., Zuzek D. (2012). Rozwój rynków odnawialnych zrodel energii w Polsce w świetle idei zrownowazonego rozwoju, (Development of the renewable energy sources market in Poland in the light of the idea of sustainable development), Multiplikacny efekt vyuzitia biomasy $v$ regionalnom rozvoji, Slowacja, pp. 20-28.

6. Snarski, S.J. (2015). Kierunki i poziom wsparcia gmin w zakresie odnawialnych zrodel energii w wojewodztwie podlaskim w ramach Programu Rozwoju Obszarow Wiejskich 2007-2013 oraz perspektywy wsparcia 2014-2020. (Directions and the level of support of communes in the field of renewable energy sources in podlaskie voivodeship under rdp 2007-2013 and the prospects of support under rdp 2014-2020), Ekonomia i srodowisko, No 3(54), pp. 213-222.

7. Szczerbowki, R., Ceran, B. (2013). Mozliwosci rozwoju i problemy techniczne malej generacji rozproszonej opartej na odnawialnych zrodlach energii. (Small scale, distributed power generation based on renewable energy sources - possibilities for development, cost of electricity production, and technical problems), Polityka energetyczna, Tom 16, Zeszyt 3, pp. 193-205.

8. Sasinowsk,i M. (2017). Wsparcie gmin dla instalacji odnawialnych zrodel energii na przykladzie gminy Lomza. (Support of boroughs for renewable energy source installations, on the example of the borough of Lomza), Mlody Jurysta. 4: 66-79.

9. Sobczyk, W., Baran, T. (2016). Konkurencyjnosc technologii odnawialnych zrodel energii. (The competitiveness of renewable energy Technologies ), Edukacja- Technika- Informatyka, No 1 (15), pp. 141146.

10. Statystyka - liczba ludnosci w gminie Koronowo stan na dzien 31 grudnia 2018 r. (Statystics - the population of the borough of Koronowo as of 31 December 2018), www.bip.koronowo.pl/?cid=509. Access: 21.01.2019.

11. Wielewska, I. (2015). Ecological investments as a necessary condition for sustainable development of agribusiness companies [in:] Economic Science for Rural Development. Rural Development and Entrepreneurship. Proceedings of the International Scientific Conference, No 39, Latvia University of Agriculture, Jelgava, pp. 47-56.

12. Wielewska, I. (2016). Position of energy obtained from agricultural biogas in sustainable power industry. Economic Science for Rural Development. Proceedings of the International Scientific Conference, No 42, Latvia University of Agriculture, Jelgava, pp. 179-185,

13. Wielewska, I., Plonka, A., Kupczyk, A. (2018). Renewable Energy and its Impact on the Development of Rural Areas, Economic Science for Rural Development, No 47, Latvia University of Agriculture, Jelgava, pp. 377-385. 